\title{
Change of Meaning in Space and Form of Contemporary Karo
} Architecture

\author{
Mohammed Nawawiy Loebis ${ }^{1,2}$, Imam Faisal Pane ${ }^{1,2}$, Wahyu Abdillah ${ }^{1,2}$, \\ Aurora S Lubis 1,2 \\ ${ }^{1}$ Department of Architecture, Faculty of Engineering, Universitas Sumatera Utara, Indonesia. \\ ${ }^{2}$ Laboratory History, Theory and Criticism of Architecture, Department of Architecture, Universitas Sumatera \\ Utara, Indonesia. \\ imam.faisal@usu.ac.id
}

\begin{abstract}
Karo Plateau is one of the most valuable assets for North Sumatra Province, Indonesian. In addition to fertile soil and producing good quality vegetables and fruit, this plain also has architectural heritage to be proud of. Several villages up to now can be seen and visited which stores various Karo architectural works including some traditional buildings and houses. Change with the times, the movement of people also occurs for various reasons. The development of the city in this province makes the villagers look for livelihood in the city. However, the inheritance of ancestors was still held firmly to the present with a different format. The Karo family currently lives in shophouse and is no longer in a traditional house and they have a business there. The perception of space in traditional houses really carried over in their daily lives. Using qualitative methods, this article explains the interpretation of the different perceptions of Karo people regarding the space and form of their place of residence. However, the essence or meaning that exists in the traditional Karo architecture is still approved until now in a different form and format.
\end{abstract}

Keywords: Karo architecture; space meaning; shophouse

\section{Introduction}

Over time though, changes and developments always occur on earth. Changes and developments that also occur in all aspects of human life, civilization, social culture, technology and so forth. Humans (Homo Sapiens) have lived and settled on earth since the first time they appeared, they can always survive and adapt to be able to accept change and development (Laksmi, 2006), both from other cultures and their own cultures. A group of people who have a particular social culture (thesa) may receive social culture from a community outside their group (anti-thesa), synthesizing a new form of socio-culture (The Accessible Hegelby Michael Allen, 2005).

Culture and civilization from outside can survive and the society that receives it by means of acculturation, which is where an individual obtains, adopts and adapts itself to the new cultural environment (Akarowhe, 2018). Individuals with different cultures enter a new culture that is more general but still adheres to their original cultural traditions (Paul, 2003) although some and even many of the original cultures experience acculturation, assimilation and amalgamation.

The social culture of the traditional Karo community was also not spared from this change and development into the contemporary Karo social culture today, as a result of contact with western culture brought by Dutch colonialism. With the Dutch entry into of Berastagi city, colonialism succeeded in getting its claws into Karo Land (1906), building roads in the highlands ending the isolation of traditional Karo society (1906) and Netherlands forming the capitalist-based city Berastagi (1920) by introducing commercialism and trade. The trade developed by the Dutch at that time was cabbage which was exported to Singapore at a very high price (Geoff Kushnick, 2010). 
The Dutch entered Tanah Karo by forming Berastagi city by building a trading environment along Veteran Street which was characterized by shophouses. Shophouse itself is an outside socio-cultural product, namely from South China. Shophouse model from South China is considered to be in line with the philosophy of capitalism and brought into Indonesia as well as concretization in the city of Medan on Jalan Ahmad Yani (Kesawan) around the 1800s (Harisdani, 2004) and then to the city of Berastagi than in the 1920s.

\section{Review of Literature}

\subsection{Changes of Meaning and Architecture}

Norberg-Schulz with his book Genius Locimenelaah of human phenomena makes place related to visual, ornamentation and symbolization of meaning. In contemporary Western architecture, genius loci no longer refers to the guardian spirit but refers to the atmosphere of the location or "spirit of place" (Norberg-Schulz, 1980). From the discussion it can be concluded that the meaning of genius loci in guardian spirits has changed into an atmosphere formed from the same set of building characters and natural conditions.

Changes in meaning contained in architectural products are related to changes in people's perception. Community perception is a collection of the same perception on a social structure. In social society there is an element of trust that maintains the continuity of that perception. As soon as belief changes then architecture changes, it can be proven by the historical course of religious buildings of Ancient Egyptian Architecture, which is clearly seen in the pyramid becoming a tomb shrine. Where is the belief in God manifested in the pyramid turned into belief in spirits and worship of animals (which are considered to represent supernatural powers) manifested in the shrine of the tomb (Loebis, 2004).

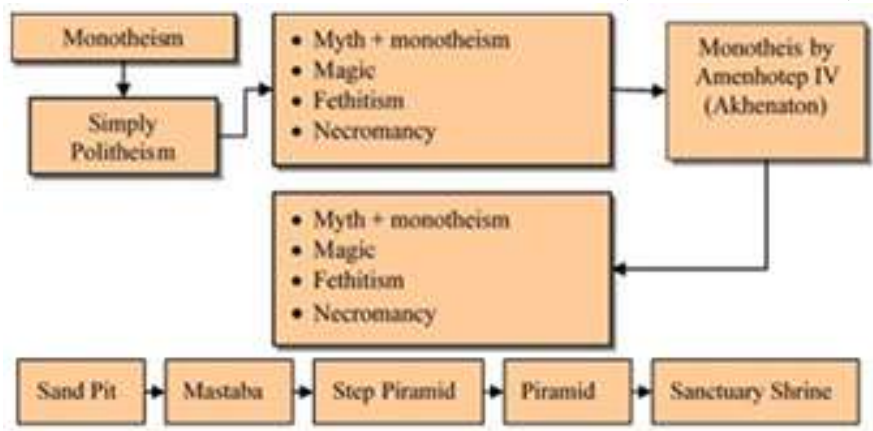

Figure 1. Developing faith and architecture in the construction of Ancient Egypt and its religious development (Loebis, 2004)

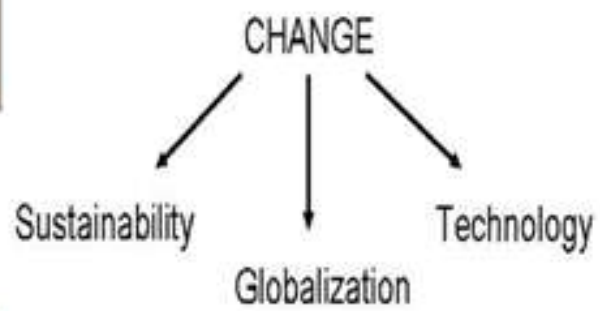

Figure 2. Change and the reltionship between Concepts (Serap, 2012)

The concept of change is the most important factor in the transformation process. Change as a common thing in all places in the world is influenced by globalization, technology and sustainability as a subtopic in architecture. Change schemes can be seen in Figure 2. In the discussion of zeitgeist changes by Ozturk, it is not clear what is meant by sustainability, whether the sustainability of external culture or local culture (Serap, 2012). While the zeitgesist referred to KishoKurokawa is how local identity entities are sustainable and sustainable, however continue to accept the cultural entity of modernity. Both of these entities are sustainable and sustainable in the socio-cultural context of contemporary Japanese society with an intercultural concept that is crystallized in the symbiotic concept (Kurokawa, 1994), (Kurokawa, 1991). 


\subsection{Meanings of Space and Form of Traditional Karo Houses}

To be able to understand and analyze changes in meaning in Contemporary Karo Architecture, a theoretical study of Karo Traditional Architecture is presented as the beginning of the movement / shift of meaning in space and form.

Architecture is very closely related to culture. Architecture will look meaningless or lifeless if it is not in accordance with the human culture that occupies it. In the past the traditional Karo people did not have the modern knowledge system as it is today. That knowledge is passed down from generation to generation like weaving done in Jambur. They built traditional houses using a mutual cooperation system, levers, connection of wooden structures with joints and pegs.

The Karo traditional community's work is besides breeding and hunting, the majority are farmers and everyone has a field whose production is stored in sapopage (rice barns). This rice barn is a separate building from a traditional house. In general, the Karo traditional house for eight families (Jabu) who have family ties with one another. The arrangement of space for each family is arranged according to the position and function of each family. Jabudapat can also be interpreted as a part of the room contained in Karo's house (Loebis, 2004).

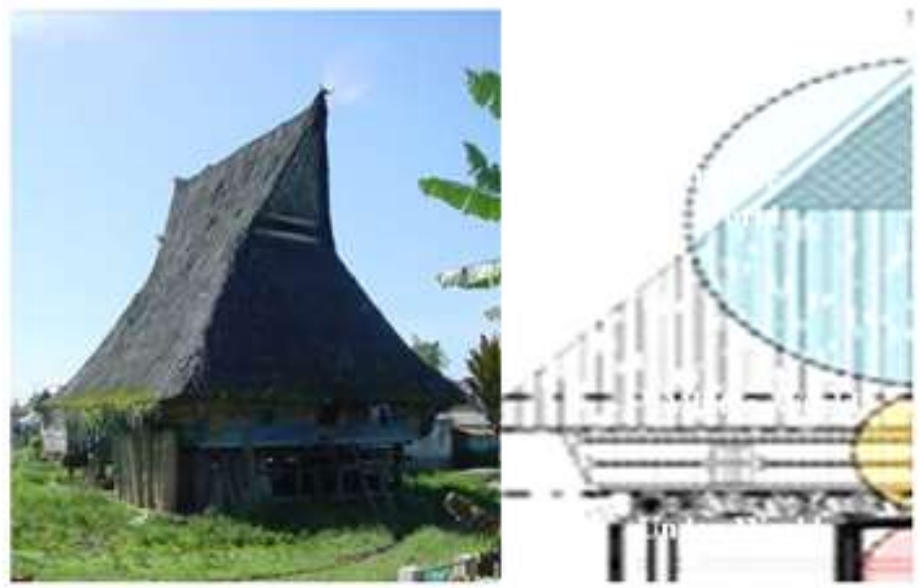

Figure 3. Siwaluh Jabu House
Figure 4. Division of world in the world view in Karo community

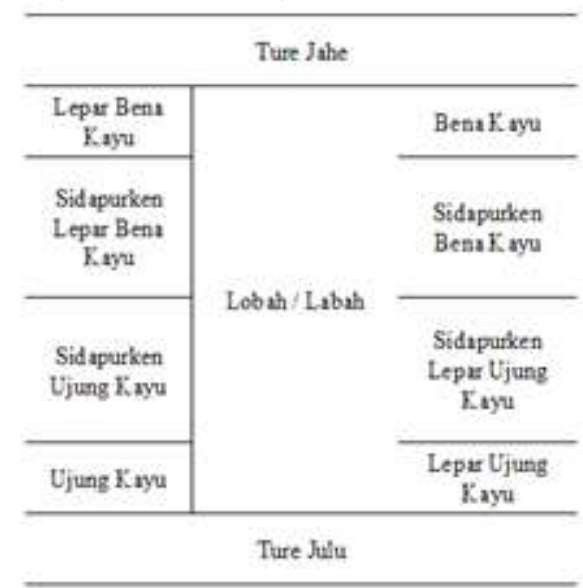

Figure 5. Karo's traditional house floor plan

In a traditional house, shared life is governed by beliefs and customs. The rules may be different from other traditional houses (eg Toba Batak traditional houses) but the principle remains the same. The underworld or DibataIteruh is symbolized by under the middle, Middle world or Middle Dibata (where humans) are represented by the space of the traditional house and the upper world Dibata Atas is symbolized by the roof of the building. This cosmology is a representation of Karo's traditional belief in Dibata (dewata) and analogous to the structure of society and kinship. The wood or elders' room in the house (homeowner) is to the left of the lobe / spider (corridor) and so on (see figure 05) but there is no dividing wall (Loebis, 2004).

Kinship system in traditional Karo customs there are three groups. The first group is a group of giving girls called Kalimbubu, which has a high position. The second group is the recipient of girls called Anak Beru and finally the group of father's descendants is called Senina. The relationship between Kalimbubu and Beru and Senina Children is called three in line (Telal Sedalanan or Sangkep Sitelu) (Loebis, 2004). According to Singarimbun (Singarimbum, 1989) the entire room can be vacated for the death ceremony. 
Budapest International Research in Exact Sciences (BirEx) Journal

Volume 1, No 4, October 2019, Page: 121-131

e-ISSN: 2655-7827 (Online), p-ISSN: 2655-7835 (Print)

www.bircu-journal.com/index.php/birex

emails: birex.journal@gmail.com

birex.journal.qa@gmail.com

\subsection{Shophouse}

Shophouse is characteristic of urban urban buildings in Asia from the 18th - 20th century. The shop house has a height of one to three floors with the function of business activities on the first floor and a residence on the second floor and above. Arrangement of the floor plan function is intended for convenience and safety of the store. Basically shophouses are lined up on a block that is restricted to the main road (front), side lanes and back roads. Each shophouse is connected to a pedestrian that is protected from tropical weather. (Nordiana, 2015) The room and shophouse are very rigid, forming a standard room with a front width between 4 to 5 meters and lengths to the rear varying from 15 to 25 meters or more.

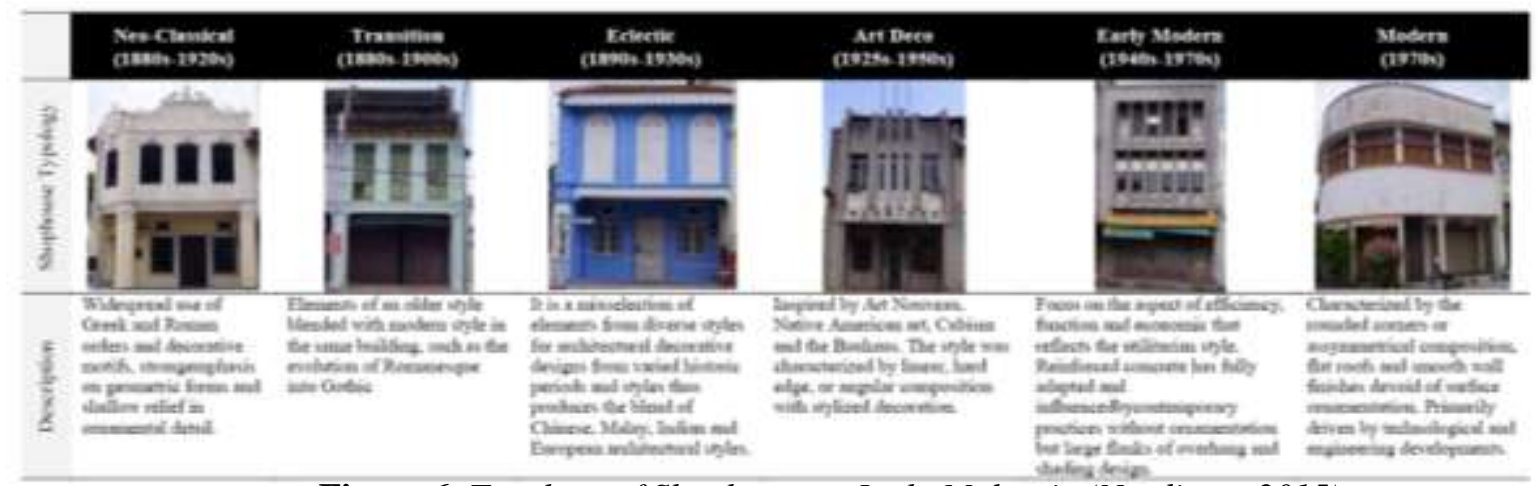

Figure 6. Typology of Shophouse at Ipoh, Malaysia (Nordiana, 2015)

Shophouses with business premises on the ground floor and residences on the upper floor are built with the upper floor more protruding forward than the ground floor so that the ground floor in front (terrace) becomes a typical arcade (Gurstein, 1990). Distribution of shop houses in Asia is in Southeast Asia, Sri Lanka and South China. All buildings including shophouses express cross-cultural correlations of various architectures reflected in arcades, cross ventilation, cantilever floors (2nd floor), roof systems and ethnic details so as to produce a new hybrid architectural style (Hassan, 2012).

As explained earlier, shop houses began to be built along Veteran Berastagi Street in 1920s. Beginning of building ownership is intended for the majority of traders and entrepreneurs who work with the Dutch colonial. After Indonesian independence until now, gradually the ownership of shop houses has gradually shifted from most ethnic Chinese to local ethnic groups, namely Karo and Batak.

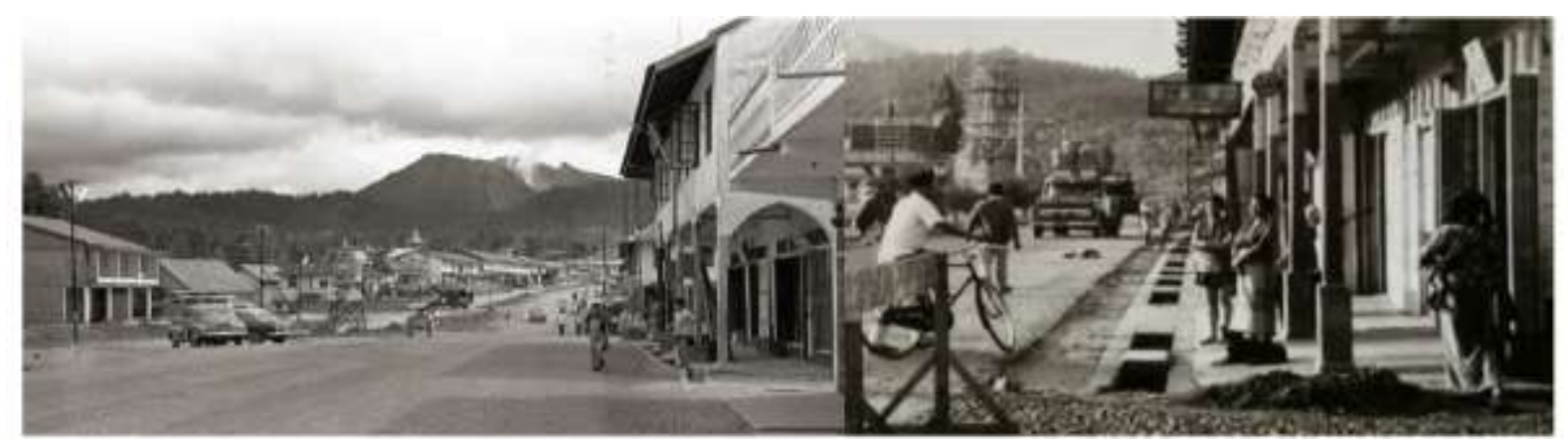

Figure 7. Berastagi City 1967. 2 storey shophouse with arcade. (source: tropenmuseum)
Figure 8. Sinabung Mount 1967 is seen from the Veterans road to Medan (source: tropenmuseum) 


\subsection{Modernity as an Agent of Change}

With the entry of Dutch colonialism into the land of Karo, it brought a flow of modernity based on capitalism and commercialism, marked by the construction of various supporting facilities and shop houses are one of them. Rigid, modular forms that can be produced repeatedly and free from locality identity are characteristics of modern architectural products. Modernity in addition to bringing new technology, from an architectural point of view, can be a capitalist approach that destroys local social and culture. As one example, the transformation of traditional jobs into jobs that are needed by capitalism provokes the movement of people from rural to urban areas as urban concentrations (Baper, 2010). Besides that, social modern society is more individualistic than communal (Kurokawa, 1991). Modernity is a radical tool with motivation for continuous change. Motivation for change is a human intervention to change cultural customs. Architecture as culture is one of the tools of change with two types of change, namely: (1) Changes in preservation (2) Changes in destructive. Baperbusi trying to map the theoretical framework for the concept of modernity in architecture, as shown in the following table (Baper, 2010).

Table 1. Theoretical Framework for the Concept of Modernization in Architecture (Baper, 2010)

\begin{tabular}{|c|c|c|c|}
\hline No. & Parameters & \multicolumn{2}{|c|}{ PossibleValues } \\
\hline \multirow{4}{*}{1.} & \multirow{4}{*}{ Modernityaims } & \multicolumn{2}{|c|}{ To rebuilttheexistingbodyofknowledge } \\
\hline & & \multicolumn{2}{|c|}{ To changeelementsof a system } \\
\hline & & \multicolumn{2}{|c|}{ To changerelationsof a system } \\
\hline & & \multicolumn{2}{|l|}{ To changeordersof a system } \\
\hline \multirow{3}{*}{2.} & \multirow{3}{*}{ Concepts of Modernity } & \multicolumn{2}{|l|}{ Present as oppositeofpast } \\
\hline & & \multicolumn{2}{|l|}{ New as contrastwithold } \\
\hline & & \multicolumn{2}{|c|}{ Transient as oppositeofperpetuity } \\
\hline \multirow{7}{*}{3.} & \multirow{7}{*}{ Modernity Motivations } & \multicolumn{2}{|c|}{ Great discoveries in thephysicalsciences. } \\
\hline & & \multicolumn{2}{|c|}{$\begin{array}{l}\text { The industrialisationofproduction, } \\
\text { whichtransformsscientificknowledgeintotechnology. }\end{array}$} \\
\hline & & \multicolumn{2}{|c|}{ Hugedemographicupheavalsandrapid urban growth. } \\
\hline & & \multicolumn{2}{|c|}{ Systems ofmasscommunication. } \\
\hline & & \multicolumn{2}{|l|}{ Powerfulnationalstates. } \\
\hline & & \multicolumn{2}{|c|}{ Masssocialmovementsofpeople. } \\
\hline & & \multicolumn{2}{|l|}{ Variablecapitalistworld. } \\
\hline \multirow{9}{*}{4.} & \multirow{9}{*}{ Modernity Features } & \multirow{5}{*}{ Architecturalpointofview } & Capitalistapproach \\
\hline & & & Formphenomenon \\
\hline & & & Processofnewness \\
\hline & & & Anti-Traditions \\
\hline & & & EstablishingnewRules \\
\hline & & \multirow{4}{*}{$\begin{array}{l}\text { Philosophicalpointofview } \\
\text { Modernizationtheory }\end{array}$} & Uncompletedproject \\
\hline & & & CivilizedPhenomenon \\
\hline & & & Multiplefaces Event \\
\hline & & & CommunicativeDiscourse \\
\hline \multirow{8}{*}{5.} & \multirow{8}{*}{$\begin{array}{l}\text { Modernity achievement } \\
\text { mechanisms }\end{array}$} & \multirow{4}{*}{ Transformations } & Reshapinganobject \\
\hline & & & Changinginnerpattern \\
\hline & & & Visual Shifts \\
\hline & & & Adaptationofcultural \\
\hline & & \multirow{4}{*}{ Change } & Variation \\
\hline & & & Culturalborrowing \\
\hline & & & Invention \\
\hline & & & Temptation \\
\hline
\end{tabular}




\section{Methodology}

Changes in meaning are part of the study of phenomenological philosophy and therefore changes in meaning at the philosophical level are also possible. For example, in a modern episteme which rests on "thinking about what is unthinkable" was first articulated by Foucault, social domination as the origin of moral dualism (good / evil) hidden by Nietzsche, transcendental subjectivity that raised natural behavior by Husserl, the question as questions that cannot be answered in traditional questions by Heidegger, the movement of subjects / objects and perceptions of the world by Merleau-Ponty to justice as a basis for deconstruction that was not built by Derrida (Schwartz, 2005).

Research related to socio-cultural phenomenology is descriptive qualitative research. Descriptive method is used to explain the phenomena that occur in the field of observation (Nasution, 2009). Meanwhile, the qualitative method is research based on intellectual understanding by finding rational and logical reasons for the phenomena of relevant data [18] (Sugiyono, 2009). This research also uses interviews with shop owners and local Karo community institutions to obtain understanding contemporary meanings which are then compared to traditional meanings to be able to see changes in the space and shape of the shop house.

\section{Results and Discussion}

\subsection{Changes of Shophouse Veteran Berastagi Street}

The site survey was conducted along Veteran Street / Jamin Ginting in Brastagi CityKaro with a road length of \pm 700 meters by taking pictures of the corridor and visual situation of the shop, both on the right and left of the road.

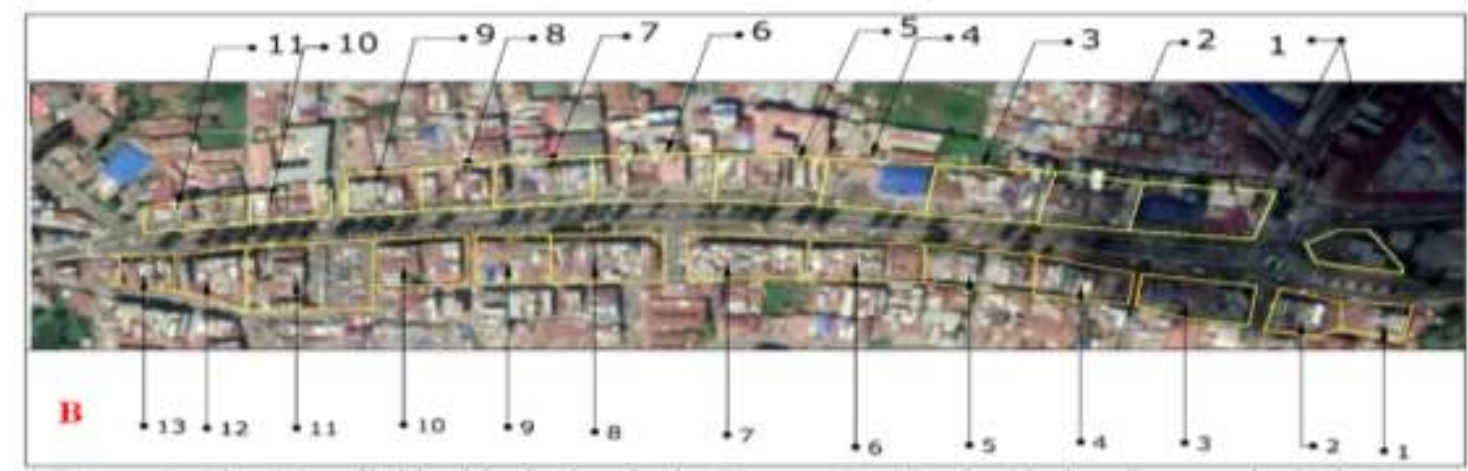

Figure 9. Citra Map divides block visual ruko Veteran St. / Jamin Ginting, Berastagi-Kab.Karo A: Row shop right next to the road from Medan; B: A row of shop houses on the left side of the road from Medan

Recordings per photo then put together for easy analysis of the shophouse appearance. Because of the limited width of the paper, the front visual of the row of shophouse is divided and the map is marked by blocks of visual image capture and merging. Based on the results of the merger, an analysis of visual recognition of the general building style of the shop house was carried out. It can be concluded that in general shophouse buildings along Veteran Berastagi Street is modern in style if compared to the typology according to Nordiana (2013). 


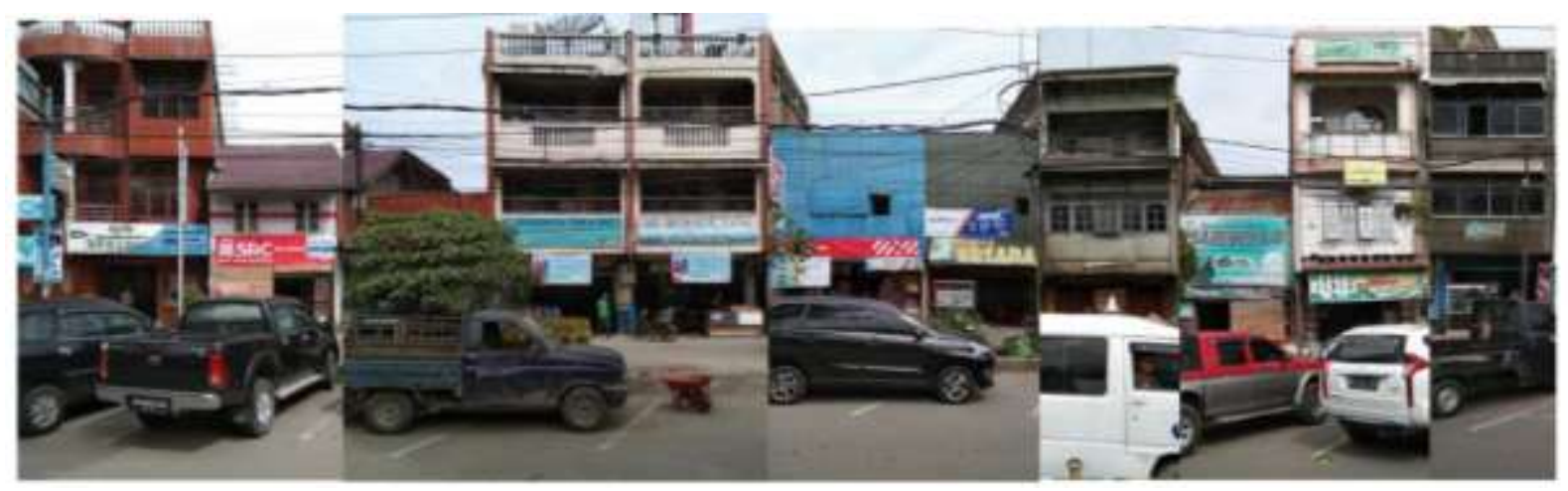

Figure 10. Shophouse Blok B6, Veteran St. - Berastagi (source: survey 2019)

Almost all shophouse buildings on both the right and left side of Jalan Veteran Berastagi Street, in a modern style. There are almost no visible traditional elements (especially ornaments) that give rise to locality identity. But overall the difference can be seen when comparing the visual atmosphere during the Dutch colonial occupation with the present. A fundamental change is that more than half of the shop houses on Veterans Street were from 2 floors to 3 floors.

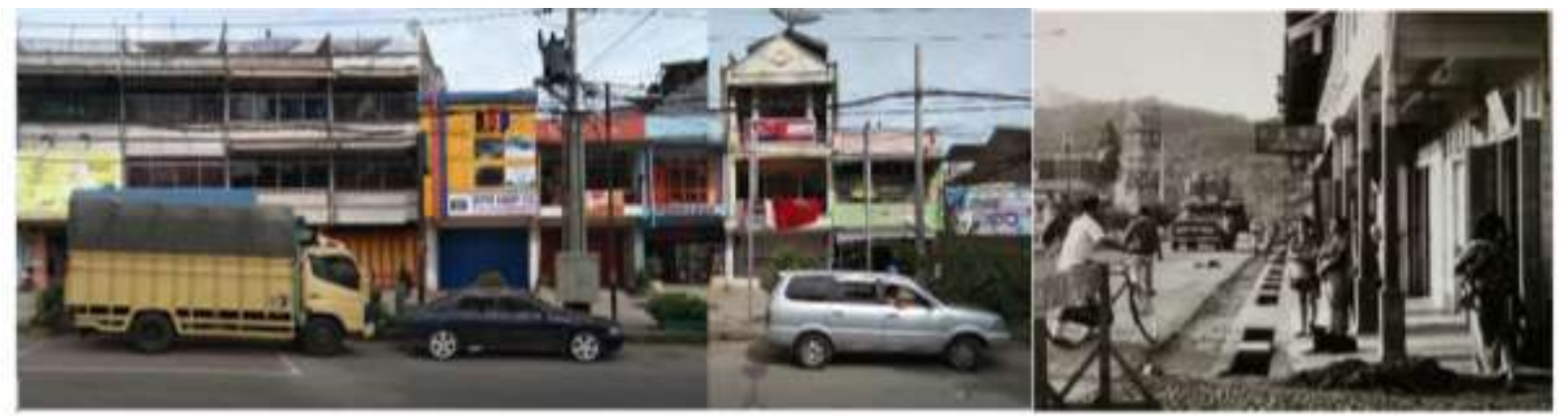

Figure 11. Shophouse Blok A6 (source: survey 2019)

Figure 12. Shophouse nearby Joeang Monument (source: tropenmuseum)

The three-storey shophouse building cannot be analogous to the vertical division of traditional Karo houses (the lower, middle and upper world) but can be concluded as a change due to modernity, namely the concentrated movement of people to make urban land making land prices more expensive so that the 2-storey building of colonial relics becomes 3-storey building. This is in accordance with Baper's statement (Baper, 2010), the concentration of human movements in urban areas has led to an increasingly expensive land price. In addition, the natural conditions surrounding the city of Berastagi are mountains so that the available flat land is quite minimal.

Karo traditional building as a whole has a wooden structure, while the 1920s shophouse buildings are also generally wooden and semi-permanent. The current of modernity also brings knowledge about reinforced concrete technology, although during the Dutch colonial occupation in Tanah Karo shop house buildings were generally semi-permanent but the technology was applied to government buildings in Tanah Karo. This knowledge was passed on from Dutch architects to local artisans, and local craftsmen applied it vernacular in time to support the change of two-storey shop houses to three floors or at least convert semi-permanent shop houses to permanent buildings with reinforced concrete technology. 


\subsection{Contemporary Social Culture at Jalan Veteran Shop House, Berastagi}

Based on direct observations in the field, the majority of shop-house owners along Jalan Veteran Berastagid are predominantly Karo, Batak and Chinese. The observations were directed at Karo ethnic store owner. The types of businesses in a row are trading, service and eating / drinking, and no longer work as a farmer. The business activities carried out are generally carried out on the ground floor of the shop house as a characteristic of modern sociocultural society. However, based on deeper observations, it turns out that Karo tradition social activities are also carried out on the ground floor, such as marriage (interviews) and death (direct observation). The two traditional Karo social activities do take place temporarily, namely to temporarily function or stop commercial activities and vacate the ground floor room. This analogy can be compared with Singarimbun's opinion (Singarimbun, 1989) on the traditional Karo house (siwaluhjabu) that such traditional adat activities take place in a contemporary manner at a shophouse.

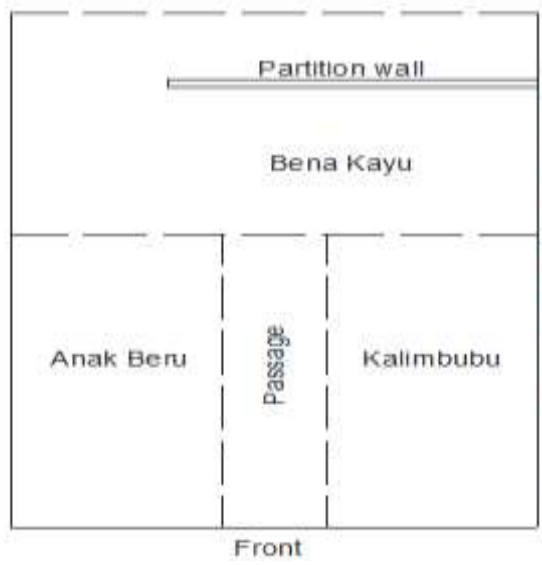

Figure 13. Floorplan of ruko segmentation during traditional ceremony (source: data processing)

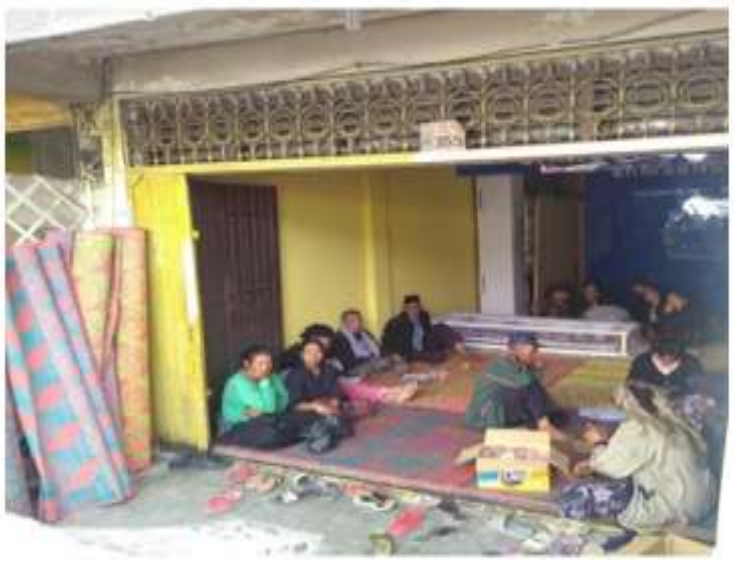

Figure 14. Front space of house (commercial abstract space) temporarily used for traditional Karo events(source: survey)

Based on observations, we get the fact that generally in a 3-storey shop house, the main bedroom for shop-house owners is on the top floor ( $3^{\text {rd }}$ floor) at the front near the road before the small terrace space. The position of this room is the same if the storehouse has 2 floors. Based on the results of the interview, the position of the main bedroom leading out of all the rooms on the top floor is to confirm the shop house owner and if the shop house owner is a child, then the parents are in the front ( $2^{\text {nd }}$ floor ) or on the 3rd floor in front too. Given age, then it will be difficult for older people to go upstairs. But it was ignored as an affirmation of the position of parents or shopkeepers in the family.

With a floor plan layout in such a way where the stairs are on the left then automatically all bedrooms are on the left side of the shop house. When compared with the traditional house siwaluhjabu, the position looks the same on the left side of the lobe / spider or hallway. However, from the interviews, their knowledge of traditional floor plan arrangements has been blurred or not clearly understood (has been abandoned). Besides that, if you compare vertically the traditional house with a three-storey shop house, then the position of the main bedroom is actually in Dibata Atas, or the traditional cosmological space of Karo in its traditional house. Old belief has long been lost by the spread of Protestantism by the Dutch colonial and formerly Islam, so the position of Dibata is replaced or represented by parents or shopkeepers with the condition that their understanding of the tradition has been lost. 


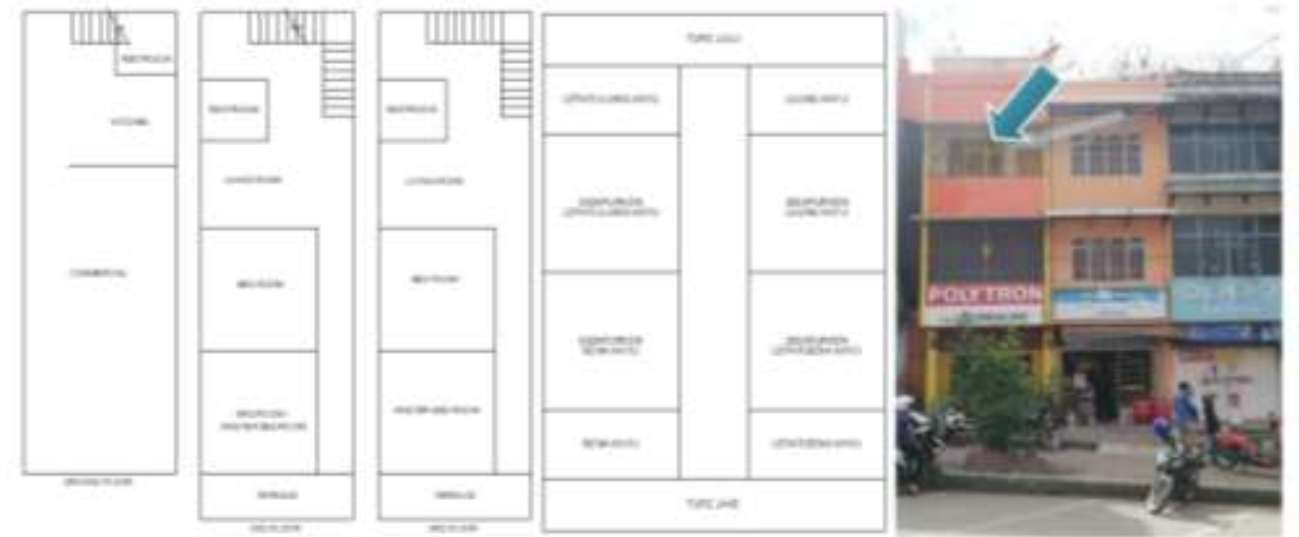

Figure 15. Typical house shop floor plan, Veteran Street, Berastagi (source: survei 2019)
Figure 16. Siwaluh Jabu Figure 17. Blue arrow, shop floor plan (source: Loebis house owner's room / parent's N.[12)) (source: survei 2019)

In figures 15 and 16 it can be compared that the function of a shop house can actually accommodate half of the function of a traditional Karo house if it is two floors, or it can even accommodate the customary space as a whole but vertically with a change of trust as the basis. Therefore, the contemporary Karo family structure will be the target of further research on a three-storey shop house. The signal of the hypothesis shows that there is excessive space if it is only for shopkeepers and their children. Meanwhile, the front porch of shop houses on the 2nd and 3rd floors can be analogous to the ginger ture of a traditional house. Some of the analogies' compatibility can occur even if not with traditional awareness or understanding that has been lost.

\section{Conclusion}

The movement of traditional inhabitants from traditional villages to urban cities is a form of modernity (Baper, 2010), this is reinforced by the statement of Singarimbun (Singarimbun, 1898) the factors that influence the movement are internal village problems and the desire for more privacy and the desire to learn in modern schools in urban big cities, such as Medan. Social culture of the work of farmers and hunting in Karo community turns into traders after occupying the building. In addition, individualism also becomes the character of its inhabitants rather than communal houses with massive walled space division.

The agent of change is mordenitas, bringing shop houses to exist in the city of Berastagi bequeathing modern technological culture. However, a sustainable culture is also found where shop houses are their containers, or it can be said that the Karo community can adapt to the rigid space and form of shop houses, which are imbued with traditional socio-cultural activities, although only temporally and with most traditional awareness lost. Building shop houses 2 to 3 floors can be built independently by local craftsmen (vernacular) although they do not accept academic construction knowledge as a legacy of modernity. In the building's facade there is no local identity, like a shop house in Jalan Ahmad Yani or a shop house in Ipoh and Little India, which gives rise to the identity of the shop owner.

Based on the theory of the framework of modernity in architectural changes by Baper (Baper, 2010) and the discussion of the research, a framework of change can be arranged that underlies the acceptance of shop houses and the adaptation of the Karo community, which is shown in the following schematic drawings. 


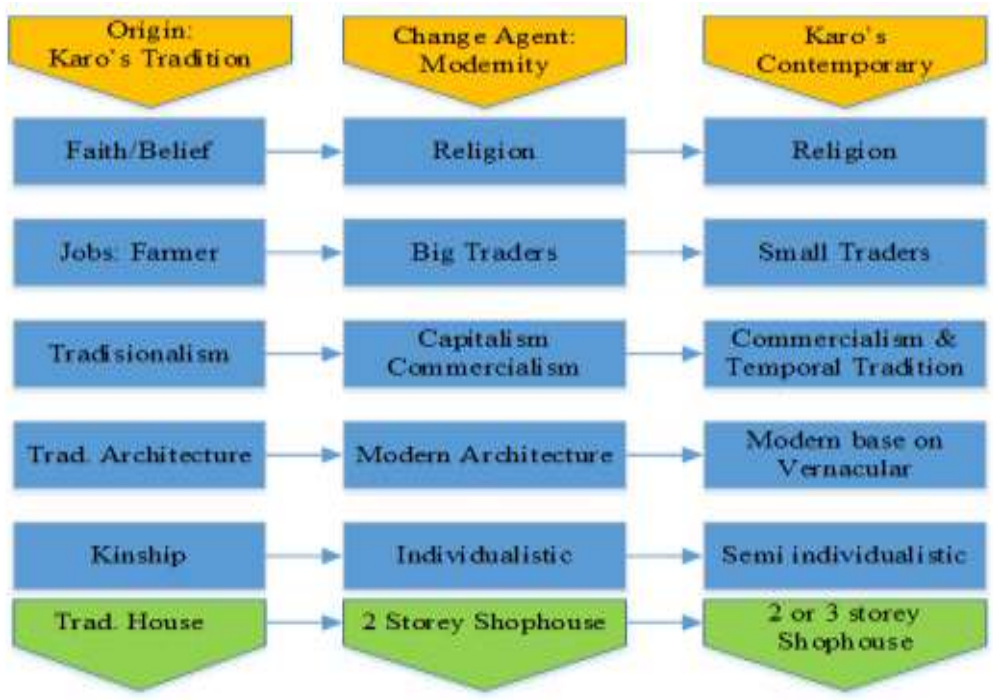

Figure 18. The Basic Framework of Change from Traditional Karo to Contemporary Karo

\section{Acknowledgments}

This research can be carried out with the help of various parties, especially from Lembaga Penelitian Universitas Sumatera Utara in accordance with USU TALENTA Research Implementation Contract 2019 Fiscal Year Number: 4167 / UN5.1.R / PPM / 2017, April 1, 2019. The author would like to thank you profusely for the assistance provided.

\section{References}

Akarowhe K. (2018). Effectsand Remedies to Cultural Shock on the Adolescent Students. Sociology International Journal 2(4): 306-309. DOI: 10.15406/sij.2018.02.00063

Baper, Salahaddin Yasin. Hassan, Ahmad Sanusi. Mustafa, Faris Ali\& Ismail, Susan Tahir(2010) A Theoretical Study on Modern it and Transformation in Architecture. 14th International Plan Ning History Society Conference.

Dr. Geoff Kushnick 2010 Bibliographyof Works onthe Karo Batak of North Sumatra, Indonesia: Missionary Reports, Anthropological Studies, and Other Writingsfrom 1826 to the Present. Department of Anthropology University of Washington, Seattle.

Gurstein, P. (1990). Malaysian Architectural Heritage Survey: A Handbook. Badan Warisan Malaysia.

Harisdani D, (2004), Identitas Fungsi Ruko Kesawan, e-USU: repository@usu.ac.id. Universitas Sumatera Utara

Hassan, A.S, \&CheYahaya, S. R. (2012).Architecture and Heritage Buildings in Georgetown Penang. Penerbit Universiti Sains Malaysia.

Kurokawa, Kisho. (1991). Intercultural Architecture - The Philosophy of Simbiosis, Academic Edition.

Kurokawa, Kisho. (1994) The Philosophy of Symbiosis, Academic Edition. Ernst \&Sohn. ISBN: 1-85490-304-7

Laksmi G. Siregar. (2006). Makna Arsitektur: Suatu Refleksi Filosofis. Universitas Indonesia press. ISBN: 979-456-318-8 
Loebis, N et al. (2004). Raibnya Para Dewa: Kajian Arsitektur Karo, Medan.

Loebis, M. Nawawiy\& Abdillah W. (2004). Arsitektur Mesir Kuno: 5.000 - 30 S.M. Penerbit: Bina Teknik Press.

Michael Schwartz (2005), Introspectionand Transformation in PhilosophyToday. A Feast of Logos: Essays in Commemoration of the Tenth Anniversary of the Georgia Continental Philosophy Circle, eds. Jason Wirth, Michael Schwartz, and David Jones (Georgia PhilosophySeries, Ch1), pp. 3-16.

Muhadjir, Noeng. (1996). Metodologi Penelitian Kualitatif. $3^{\text {rd }}$ Edition. Rake Sarasin. Yogyakarta

Norberg-Schulz C. (1980). Genius Loci: Towards a Phenomenology of Architecture (Rizzoli University of Michigan) ISBN: 0847802876

Nordiana, Wan et al(2015). An Overview on the Typology of Shophouses' Faça deat the Heritage Area in Ipoh City. Research Gate. DOI: 10.13140/RG.2.1.1937.0962.

Paul N. Lakey 2003 Acculturation: a Review of the Literature, Intercultural Communication Studies XII-2, pp.103-118

Serap Durmus Ozturk. (2012). Change and Transformation in Architecture: On the Concept of Zeitgeist, Research Gate: GBER Vol8 No pp.23-36

Singarimbun, Masri. (1989) Rumah Adat Karo dan Perubahan Sosial. Jurnal Humaniora, Faculty of Cultural Sciences, Universitas Gadjah Mada, Indonesia, No 1. ISSN: 23029269.

S. Nasution, M.A. Metode Research (Penelitian Ilmiah), (Jakarta: PT Bumi Aksara, 2009). P. 23

Sugiyono. (2009). Metoda Penelitian Kualitatif dan Kuantitatif dan R\&D (CV. Alfabeta Bandung)

The Accessible Hegelby Michael Allen Fox. Prometheus Books. 2005. p. 43. Alsosee Hegel'spreface to the Phenomenology of Spirit, trans. A. V. Miller (Oxford: ClarendonPress, 1977), secs. 50, 51, pp. 29-30. 